\title{
Comprehensive assessment and evaluation of selected wheat varieties for their relationship to chapatti quality attributes
}

\author{
Rai Muhammad AMIR ${ }^{1 \star}$ (D), Muhammad Naveed HUSSAIN ${ }^{1}$, Kashif AMEER ${ }^{1}$, Anwaar AHMED ${ }^{1}$, Asif AHMAD ${ }^{1}$, \\ Muhammad NADEEM ${ }^{2}$, Aayesha RIAZ ${ }^{3}$ Muhammad Farhan Jahangir CHUGHTAI ${ }^{4}$, Adnan KHALIQ ${ }^{4}$, \\ SAMREEN AHSAN ${ }^{4}$, Rukhsana KAUSAR
}

\begin{abstract}
Wheat is consumed as staple food by majority of population in Pakistan. This study was aimed to assess the effects of recently introduced five cultivars of wheat (Ojala 2016, Borlaug 2016, Johar 2016, Gold 2016 and Fatehjang 2016) for chapatti quality. Results for different physical, chemical, rheological and sensory parameters revealed significant $(p<0.05)$ differences between the cultivars studied. The flours obtained from wheat cultivars Fatehjang 2016, Borlaug 2016 and Gold 2016 demonstrated increasing tendency in protein content and dry and wet gluten. Wet gluten was significantly higher in Fatehjang 2016 (30.08\%) and significantly lower (26.21\%) in wheat variety named Gold 201. Fatehjang 2016 and Borlaug 2016 showed the most appealing physical properties among all cultivars. On the basis of rheological and sensory parameters, Fatehjang 2016 was found to be the most suitable variety for production of chapatti followed by Borlaug 2016.
\end{abstract}

Keywords: wheat varieties; physicochemical; rheological properties; sensory evaluation; chapatti.

Practical Application: Topic of study is about utilization of newly introduced wheat varieties to formulate chapattis of improved rheological and organoleptic properties.

\section{Introduction}

Chapatti is a flat, unleavened, hot-plate-baked product prepared from whole-wheat flour which is commonly widespread in Pakistan. It is the main part of food for most of the population and serves as an economical source of protein and energy. Usually it is consumed fresh in households and out of home. However, today is the industrial production of chapatti with fully automated chapatti making machine is also established. Whole-wheat flour is the major raw material for chapatti and therefore the characteristics of wheat flour directly affect the quality of the chapatti (Kundu et al., 2017).

Wheat (Triticum aestivum) is one of the most widely cultivated crops in the world with an average annual production more than 700 million tons in the last decade (Kundu et al., 2017). Production forecasts for season 2017/18 nearly 750 million tons, while consumption is estimated at 720 million tons. The expected increase in world population, expected to reach 9.7 billion by 2050 , suggests that the global agricultural production must rise by $25-70 \%$ from the current levels (Crist et al., 2017). This big challenge is even greater given the expected climate change scenarios. Pakistan is 8th largest wheat producer accounting for $3.17 \%$ of world wheat production. It contributes $13.8 \%$ of added value to agriculture and $30 \%$ to total GDP of Pakistan.
Wheat is used directly by $65 \%$ of people as food, about $21 \%$ for animals feed, $9 \%$ for wheat seeds and about $7 \%$ for the industry. Approximately $80 \%$ of wheat grain is used to prepare various domestic products such as chapatti and its different variations named tandoori roti, naans, parathas and poories. Approximately, 21\% of wheat is used in various industries and bakeries for bakery products such as bread, biscuits, pizza, cakes and pastries (Tahseen et al., 2014). The quality of wheat generally depends on genomic factors, environmental factor, growing surface and agricultural practices that exist at different stages of growth. Wheat product quality is closely related to physical, chemical and nutritional properties of wheat. Quality of protein and quantity is a significant factor affecting product quality (Zabed et al., 2017). The variety of wheat for the evaluation of useful information makes it possible to distinguish different varieties. Cultivators, millers and bakers choose these methods to distinguish wheat from production purpose (Wani et al., 2016).

Five wheat varieties were analyzed in this project based on their physico-chemical and rheological properties in order to evaluate their suitability for chapatti quality. The need for this study was to evaluate different types of wheat varieties that has not been analyzed before for any bakery product and to choose the best wheat variety among those varieties suitable for chapatti production. The aim of this discovery was to assess the quality of chapatti making whole 
wheat flour acquire from different wheat varieties by coordinating physico-chemical, rheological and sensory quality tests. The results may help in choosing a better material such as whole wheat flour for preparing a chapatti at home and at the business level.

\section{Materials and methods}

\subsection{Wheat varieties procurement}

Five commercially available recent wheat varieties, such as Ojala 2016, Borlaug 2016, Johar 2016, Gold 2016 and Fatehjang 2016 were procured from the Ayub Agricultural Research Institute Faisalabad.

\subsection{Cleaning of grains}

The grains of each wheat variety were cleaned manually to remove damaged seeds, dust particles, seeds of other grains/crops and metal particles. All the chemicals and reagents used in this study were of analytical grade and were purchased from (Sigma-Aldrich, St. Louis, USA). The cleaned samples were subjected to tampering followed by milling through Quadrumate Senior Mill in accordance with American Association of Cereal Chemists (2000) standard. Wheat flour were collected at various extraction rates and were further used for chemical analysis.

\subsection{Physical characteristics}

Each wheat variety was analyzed for different physical parameters such as grain size, thousand kernel weight (TKW), test weight and extraction rates according to the methods described in American Association of Cereal Chemists (2000).

\section{Grain size}

The length and width of one hundred wheat grains were taken randomly and determined by micrometer (vernier caliper) as per method of American Association of Cereal Chemists (2000).

\section{Thousand Kernel Weight (TKW)}

TKW of each wheat variety was measured in grams/1000 kernels. $50 \mathrm{~g}$ sample of each wheat variety was drawn randomly and thousand kernel weight was measured by counting and weighing the unbroken, clean and sound kernels. The measurements were recorded in triplicate manner according to the method given in American Association of Cereal Chemists (2000).

\section{Test weight}

The test weight of each wheat variety was determined by the method given in American Association of Cereal Chemists (2000) (method No. 55-10). For this purpose, 1 L vessel was overloaded with wheat grains leveled and weighted on an electric parity. The test weight was expressed in $\mathrm{kg} / \mathrm{hl}$.

\section{Wheat milling}

The tempered wheat was milled through Brabender Quadrumate Senior Mill (Brabender Instruments, Inc.) to get break, reduction and straight grade flour according to the method
No. 26-95 described in American Association of Cereal Chemists (2000). Wheat flour were collected at various extraction rates and were further used for chemical analysis.

\subsection{Chemical analysis}

The flour samples were examined for the moisture, protein, fat, fiber and ash contents according to the methods of American Association of Cereal Chemists (2000).

\section{Moisture content}

The moisture content was examined by American Association of Cereal Chemists (2000) Method No 44-19. $3 \mathrm{~g}$ flour sample of each variety was taken in crucible and placed in air forced draft oven at a temperature of $105+5 \mathrm{C}$ till to constant weight. The moisture content was measured by the Equation 1 given below.

Moisture content $\%=\frac{\text { Weight of sample }- \text { Weight of dried flour sample }}{\text { Weight of sample }} \times 100$

\section{Ude protein}

The determination of protein was carried out through Kjeldhal's method as defined in American Association of Cereal Chemists (2000). Method No 46-10 was used to measure the nitrogen content in different wheat flour samples by digesting the sample with concentrated $\mathrm{H}_{2} \mathrm{SO}_{4}$ in the presence of catalysts. During digestion, the organic compounds was oxidized and the nitrogen is converted to ammonia sulphate. During distillation in an alkaline media the ammonia is liberated which is collected in a flask containing $4 \%$ boric acid solution using methyl red as an indicator. Determined the nitrogen content of each samples by titrating against $0.1 \mathrm{~N} \mathrm{H}_{2} \mathrm{SO}_{4}$ solutions and the protein $\%$ was measure by multiplying the nitrogen $\%$ with a conversion factor 6.25. The nitrogen content was measured by the Equation 2 given below.

Nitrogen $\%=\frac{(\mathrm{B}-\mathrm{S}) \times \mathrm{N} \times 9.0014 \times \text { Volumr used }}{\text { Weight of sample } \times \text { volume used }} \times 100$

Ude fat

The fat content in flour sample of every wheat assortment was dictated by running dried examples through soxhlet apparatus for 2-3 hours utilizing petroleum ether as dissolvable as per American Association of Cereal Chemists (2000). The fat content was measured by the Equation 3 given below.

Fat $\%=\frac{\text { Weight of fat }(\mathrm{g})}{\text { Weight of sample }(\mathrm{g})} \times 100$

\section{Ude fiber}

Crude fiber the determination of in flour and chapatti samples, the defatted samples $(2.0 \mathrm{~g})$ was digested with 1.25 percent $\mathrm{H}_{2} \mathrm{SO}_{4}$ followed by $1.25 \% \mathrm{NaOH}$ solution as describes by American Association of Cereal Chemists (2000). Filtration was performed to separate residue after treating with $\mathrm{H}_{2} \mathrm{SO}_{4}$ and $\mathrm{NaOH}$ and was further dried in hot air oven. The crude fiber was measured by the Equation 4 given below. 
Crude Fiber $\%=\frac{\text { Weight loss on ignition }(\mathrm{g})}{\text { Total Weight of sample }(\mathrm{g})} \times 100$

\section{$h$ content}

The ash content was determined in each flour samples according to method in American Association of Cereal Chemists (2000) method N0. 08-01. 5 g sample was dried in oven charred on the burner and then ignited in the muffle furnace at which the temperature of $550-600{ }^{\circ} \mathrm{C}$ for $5-6 \mathrm{~h}$ or till appearance of grayish ash. The ash content was calculated using Equation 5 given below:

Ash $\%=\frac{\text { Weight of ash }}{\text { Total Weight of sample }} \times 100$

$y$ and wet gluten

Dry and wet gluten contents in various wheat flour samples were measured by hand washing method as described by method of American Association of Cereal Chemists (2000) (method No. 38-10). Dough was made by including $15 \mathrm{~mL}$ of water $25 \mathrm{~g}$ of flour in a bowl. The dough was permitted to represent $1 \mathrm{~h}$ and afterward plied kneaded under a surge of cold tap water, letting the washings went through a fine strainer until all starch and dissolvable matter was removed. Starch expulsion was test by pressing a little water from the ball in to container and clear, chilly water, cloudiness showed that starch is as yet present. The ball was kept in cold water for $1 \mathrm{~h}$ and water was crush with hands. At that point the ball was put in a tarred, level base dish and weighted as clammy gluten. The deliberate of dry gluten the ball was dried in an air constrained draft stove at temperature of $100 \pm 5^{\circ} \mathrm{C}$ till constant weight.

\subsection{Dough rheological properties}

\section{Farinographic properties}

The flour tests of every wheat varieties were assessed for rheological properties by utilizing Brabander farinograph furnished with $50 \mathrm{~g}$ bowl concurring system recommended method in American Association of Cereal Chemists (2000) (Method No. 54-21). The properties of dough were gotten by farinogram created by Farinograph. Dough attributes, for example, batter dough development time, tolerance index, water absorption, dough stability and softening of dough was interpreted from farinogram produced by Farinograph.

\section{Mixographic properties}

Mixographic characteristic of flour was assessed using mixograph according to the procedure described in American Association of Cereal Chemists (2000).

\subsection{Chapatti preparation}

The dough for chapatti was made by flour with predetermined amount of water for three to four minutes in mixer and then allowed to relaxation for $25 \mathrm{~min}$ before production dough balls. Dough ball were round and rolled to achieve a uniform thickness.
The dough sheet was heated on thermostatically controlled chapatti production plate with cut off temperature of $220^{\circ} \mathrm{C}$ for 40 and $100 \mathrm{~s}$ for side 1 and side 2 . Puffing of chapatti was done on gas flame with temperature range of $290-330^{\circ} \mathrm{C}$ for puffing time of 25 s (Ribotta et al., 2001).

\subsection{Sensory evaluation of chapatti}

After baking of chapatti, the sensory evaluation was performed by a trained panelists for different characteristics i.e. color, aroma, texture, puffing height, crumb color and bake evenness. A nine-point hedonic scale ( $1=$ extremely dislike, 3 = dislike, 5 = fair, 7 = good, $9=$ extremely like) as defined by Villanueva et al. (2005) was used for sensory evaluation.

\subsection{Statistical analysis}

All the experiments were performed in triplicate $(n=3)$ and data was recorded as mean values along with standard deviation (S.D.). The data was analyzed by one-way analysis of variance (ANOVA) and differences between the means were elucidated by student t-test $(p<0.05)$. All statistical analysis was carried out by Origin Pro 2015 (Microcal Software Inc., Northampton, MA, USA) and Microsoft Excel (ver. 2016, Microsoft Corp.).

\section{Results and discussion}

\subsection{Physical characteristics of wheat}

The physical and chemical parameters of grain and whole-wheat flour of five wheat varieties were determined to evaluate their contribution to the quality of chapatti shown in Figure 1. Thousand kernel weight (TKW) of grains indicates the grain quality i.e. longer, round and sound grains generally have a higher thousand kernel weight. The collected data indicated that good chapattis were obtained from wheat cultivars with a larger thousand kernel weight. The results for TKW ranged from 36.00 to $49.3 \mathrm{~g}$ in different wheat varieties. The most significant TKW (49.33 g) was found in case of Fatehjang 2016 followed by Johar 2016 (36.00 g). The test weight values ranged from 69.25 to $80.35 \mathrm{~kg} / \mathrm{hl}$. The most significant test weight $(80.35 \mathrm{~kg} / \mathrm{hl})$ was measured in case of Borlaug 2016 whereas, wheat variety Ojala 2016 showed the lowest test weight $(69.25 \mathrm{~kg} / \mathrm{hl})$. The extraction rate ranged from 61.22 to $72.79 \mathrm{~g}$ among the tested wheat varieties. The highest extraction rate $(72.79 \mathrm{~g})$ was recorded in Borlaug 2016 and the lowest value (61.22 g) was found in Ojala variety 2016. The present findings showed a significant difference $(p<0.05)$ between various wheat varieties. These results of present study are in accordance with those Asim et al. (2018) who has reported the thousand kernel weight to be in range from 34.52 to $45.16 \mathrm{~g}$. Grain length and width were found to be highest in case of Ojala 2016 followed by Borlaug 2016. Extraction rates for all wheat cultivars were recorded in the range of 58.34 to $73.03 \mathrm{~g}$. Significant differences $(p<0.05)$ were observed in case of extraction rate. Highest extraction rate was found in Borlaug 2016 (73.03 g) followed by Johar 2016 (65.67 g). Ojala 2016 exhibited the lowest extraction rate of $62.0 \mathrm{~g}$. These results are also in line with findings of Amir et al. (2013) who found physical characteristics in different what varieties. Various 


\section{Physical characteristics}

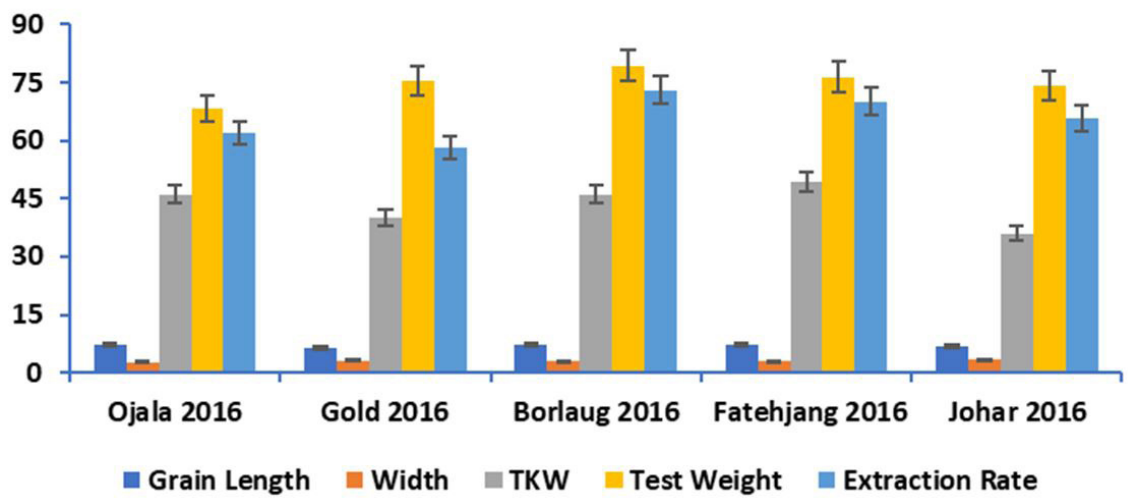

Figure 1. Graphical results shown Physical characteristics of wheat of different wheat varieties.

\section{Chemical composition}

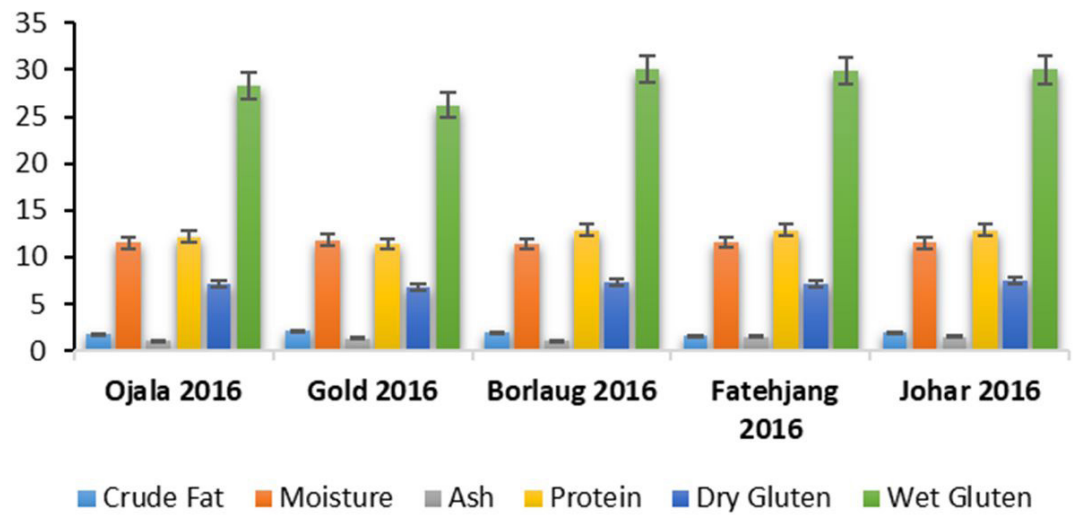

Figure 2. Graphical results shown chemical composition of different wheat varieties.

published researches have confirmed that environmental factors fertilizer usage may exert their influences on test weight, TKW quality and yield of flour. Asim et al. (2018) reported similar findings and concluded that milling led to achievement of extraction rate in the range of 60.32 to $73.41 \mathrm{~g}$.

\subsection{Chemical composition}

The results pertaining to chemicals composition of different wheat varieties showed significant $(p<0.05)$ variations as depicted in Figure 2. The moisture content of different wheat varieties was ranged from 11.40 to $11.80 \%$. Maximum moisture content $(11.80 \%)$ was found in Gold 2016 and significantly lowest (11.40\%) moisture content was measured in Borlaug 2016. Genetic compositions of grains may play contributory role in determining moisture content of wheat varieties and agronomic and climatic factors may also exert their influence (Maity et al., 2016). Grain moisture content is of paramount importance with respect to two aspects. Firstly, high moisture content may lead to increasing tendency in weight of kernel. Secondly, higher moisture content may cause decreases in overall storage period of grains (Abramson et al., 2005). Asim et al. (2018) reported the similar findings for moisture content of wheat cultivars.

Protein content values ranged from 11.20 to $12.91 \%$ for all wheat cultivars. The highest protein content $(12.91 \%)$ was recorded in Fatehjang 2016 and the lowest (11.20\%) was found in Gold 2016. These results indicated significant difference $(p<0.05)$ among wheat cultivars with respect to protein content. Similar results were reported by Asim et al. (2018) and Khan et al. (2015) who found protein content in the range of $8-15 \%$ for Pakistani wheat cultivars. Many published reports have inferred that protein content $f$ wheat is dependent on various factors, such as drought stress, soil fertility, thermal stress and agricultural practices (Li et al., 2013; Mutwali et al., 2016). Different wheat cultivars showed variations in protein content which is in accordance with the fact that protein compositions and content differences may cause significant improvement in flour quality for chappati cooking. Moreover, wheat variety with higher protein content exhibits higher economic value for baking and bread industries as compared to lower protein content wheat cultivars which are more suited for cakes and cookies manufacturing. In addition to this, type and quality of proteins 
also play influential roles in determining good baking properties (Kundu et al., 2017). Chappati quality can be assessed by using wheat protein content as an important quality indicator. Results for ash content ranged from 1.01 to $1.53 \%$. The significantly maximum ash content (1.53\%) was noted in Johar 2016 and the lowest score (1.01\%) in wheat variety Ojala 2016. Mutwali (2011) reported similar result for ash content. Ash content showed improved tendency with corresponding increases in extractions rates of wheat flours. The inherent differences of ash contents in wheat cultivars might be due to differences of environmental factors, such as soil fertility, fertilizer usage and temperature constraints. Although, ash content improvement has correlation with nutritional significance but high ash content may cause undesirable darkening in formulated dough which can exert negative impact on quality of end products. The ash contents are linked in direct manner to the bran amounts in wheat flours after milling and may serve as an indicator for evaluating baking products. The results of wet and dry gluten showed significant variability among wheat cultivars. The content of wet gluten was in the range of 26.21 to $30.08 \%$ in different wheat varieties. Wet gluten was significantly higher in Fatehjang $2016(30.08 \%)$ and significantly lower $(26.21 \%)$ in wheat variety named Gold 2016. The results indicated significant $(p<0.05)$ differences among cultivars. Wet and dry gluten can help to predict flour suitability for chapatti production on the basis of overall acceptability and selection of wheat breeding line with better chapatti quality. The contents of the wet gluten ranged from 6.81 to $7.96 \%$ in different wheat varieties. Dry gluten was significantly $(p<0.05)$ maximized in Johar 2016 (7.96\%) and significantly lower (6.81\%) in wheat variety Gold 2016. Similar results was found by Asim et al. (2018) who studied the chemical composition of Pakistani wheat varieties and reported interdependent relationship of gluten quantity with genotype specificity, agricultural practices and environmental constraints. The recent results are also parallel with the previous findings of Amir et al. (2013) who found chemical parameters in different wheat varieties.

\subsection{Relationship of flour rheological properties with chapatti quality}

Rheological properties are crucial determinant in evaluating wheat-based products. The inherent differences of farinographic characteristics among wheat cultivars might be due to changes in protein quality and quantity of wheat (Kundu et al., 2017). The results regarding rheological parameters, such as water absorption, dough stability and dough development time of different wheat varieties demonstrated significant variations in all cultivars as shown in Figure 3. The farinograph is highly useful dough testing apparatus to determine the dough rheology. The differences in the farinographic characteristics are related to the flour extraction rates and amount of endosperm as well as the quality and percentage of protein present in wheat (Kundu et al., 2017). The water absorption ranged from 46.60 to $58.11 \%$ in the tested wheat varieties. The significantly highest water absorption of flour (58.11\%) was found in Fatehjang 2016 and the significantly lowest value (46.60\%) was observed in Gold 2016 variety. Our results of water absorption were in line with the findings of Kundu et al. (2017) who reported that water absorption may serve as an important factor in determining puffed height of chapatti and bread. The inherent differences of water absorption values among wheat cultivars can be attributed to grinding method for wheat grains and dough mixing phenomenon. In another research, similar water absorption was recorded in the range of $45 \%$ to $64.72 \%$ (Mueen-ud-Din et al., 2010). The results of dough development time was ranged from 3.40 to $7.57 \mathrm{~min}$. The significantly highest dough development time of flour (7.57 $\mathrm{min}$ ) was recorded in Fatehjang 2016, whereas wheat variety Gold 2016 exhibited the significantly lowest (3.40 min) dough development time. The significantly highest dough stability of flour (15.17 min) was noted in Fatehjang 2016 and the significantly lowest value (3.29 $\mathrm{min}$ ) was found in wheat variety Gold 2016. Our result are in line with Kundu et al. (2017) and Asim et al. (2018) who found dough development time in the range of 1.45 to 11.46 min of different Pakistani wheat

\section{Rheological characteristics}

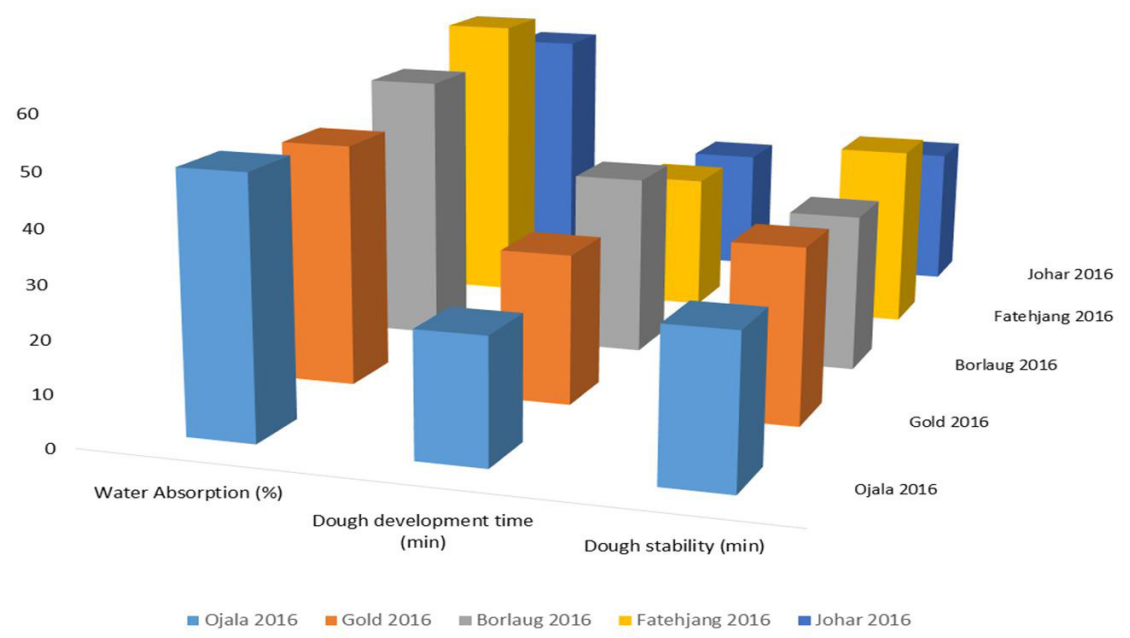

Figure 3. Graphical results shown rheological properties of different wheat varieties. 


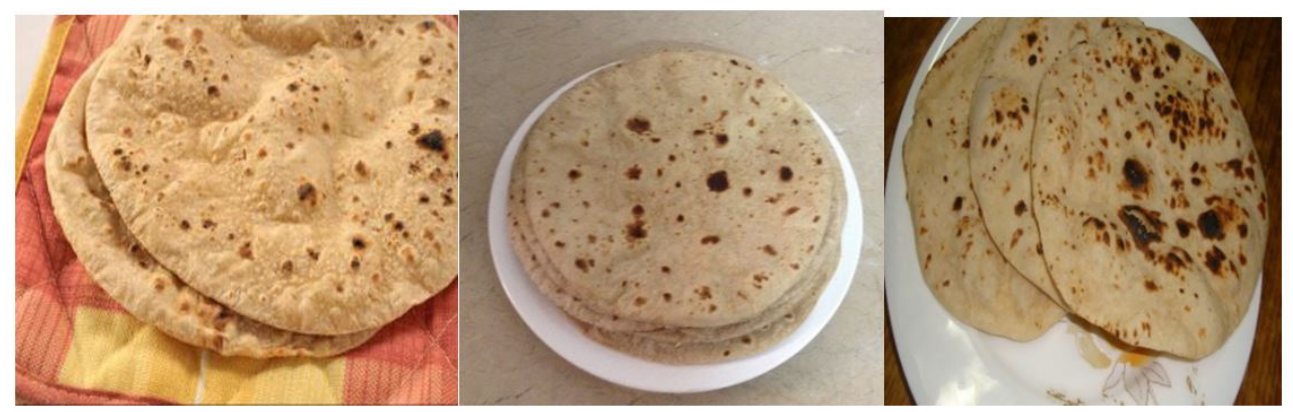

Fatehjang $2016 \quad$ Borlaug $2016 \quad$ Johar 2016

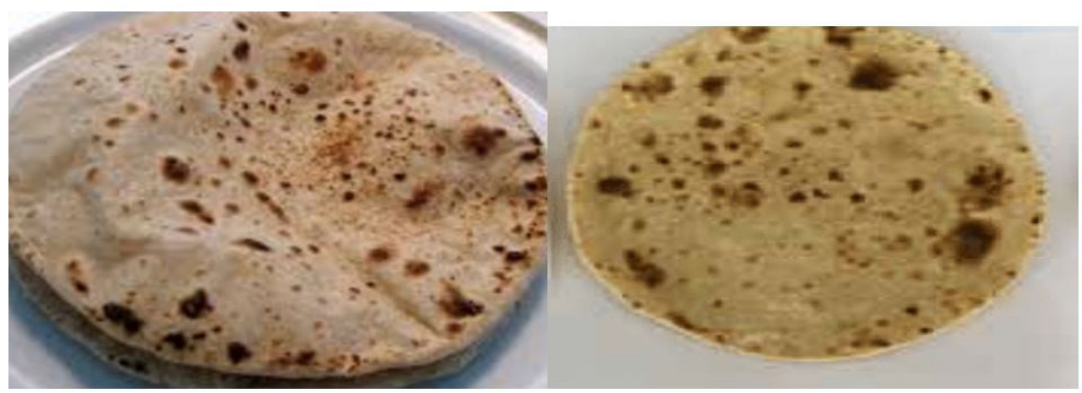

Ojala 2016

Gold 2016

Figure 4. Chapattis prepared from different wheat varieties.

varieties. Dough stability of more than 10 has been reported to be more suitable for baking purposes as it can demonstrate higher tolerance range against shear stress of mixing and can with stand for longer time interval. Stronger dough may result in tough prepared chapattis and exert an influence on overall acceptability of finished product (Kundu et al., 2017).

\subsection{Sensory evaluation of chapattis}

The chapattis prepared from various wheat varieties are shown in Figure 4. The sensory evaluation of chapattis based on scoring of puffing height, crumb color, aroma, evenness of bake and texture showed significant $(p<0.05)$ differences among all wheat cultivars. The results pertaining to sensory evaluation of chapatti prepared from wheat varieties are presented in Figure 5. The chapattis prepared from flour of different wheat varieties were evaluated for different sensory parameters. The sensory properties of the chapatti are influenced by the composition of wheat, the method of milling, storage conditions, rheological properties, kneading techniques, baking method and temperature (Kihlberg et al., 2004).

Puffing height is a very desirable feature of flat bread during baking and the consumer prefer flat bread with more puffing during baking. Puffing height for the chapattis was ranged from 5.05 to $6.44 \mathrm{~cm}$. Maximum puffing height $(6.44 \mathrm{~cm})$ was observed for chapattis prepared from variety Fatehjang 2016 followed by Ojala $2016(5.05 \mathrm{~cm})$. The scores for bake evenness of chapatti was ranged from 8.80 to 3.80 . The highest score (8.80) was assigned to chapatti prepared from Fatehjang 2016 and lowest (3.80) to Johar 2016. The sensory score for evenness of bake of variety Fatehjang 2016 was significantly $(p<0.05)$ higher while Johar 2016 exhibited lowest score as compared to all other varieties. The scores for the color of crumb of baked chapatti were ranged from 4.60 to 8.80 . Highest score (8.80) was given to chapatti prepared from Fatehjang 2016 and the lowest (4.60) to chapatti made from wheat variety Johar 2016. The results attributed to the aroma of chapatti were found in the range of 5.00 to 8.40 . The highest score (8.40) was given to the chapatti prepared from Fatehjang 2016 and the lowest (5.00) to chapattis of Ojala 2016. The sensory results for the aroma of the Fatehjang 2016 was highest and Ojala 2016 exhibited the lowest among all varieties. The scores assigned to the taste of the chapatti was significantly varied from 4.80 to 8.80 . Maximum score (8.80) was assigned to a chapatti made from Fatehjang 2016 and the lowest (4.80) to chapatti of wheat variety Johar 2016. The score for aroma of the Fatehjang 2016 variety was significantly highest and Johar 2016 was significantly lowest than the other varieties. The scores relating to the texture of the chapatti were significantly varied from 5.20 to 9.00. The highest rating (9.00) was awarded to the chapatti prepared from Fatehjang 2016 and the lowest (5.20) to Gold 2016. Similar results were also found by Asim et al. (2018) who studied the different Pakistani wheat varieties. The results of recent study is also supported by findings of Kundu et al. (2017) who reported sensory score in the range of 3.5 to 8.5. Different wheat cultivars may exhibit differences of color, taste and flavor in end products due to variability of grain hardness and 


\section{Sensory evaluation}

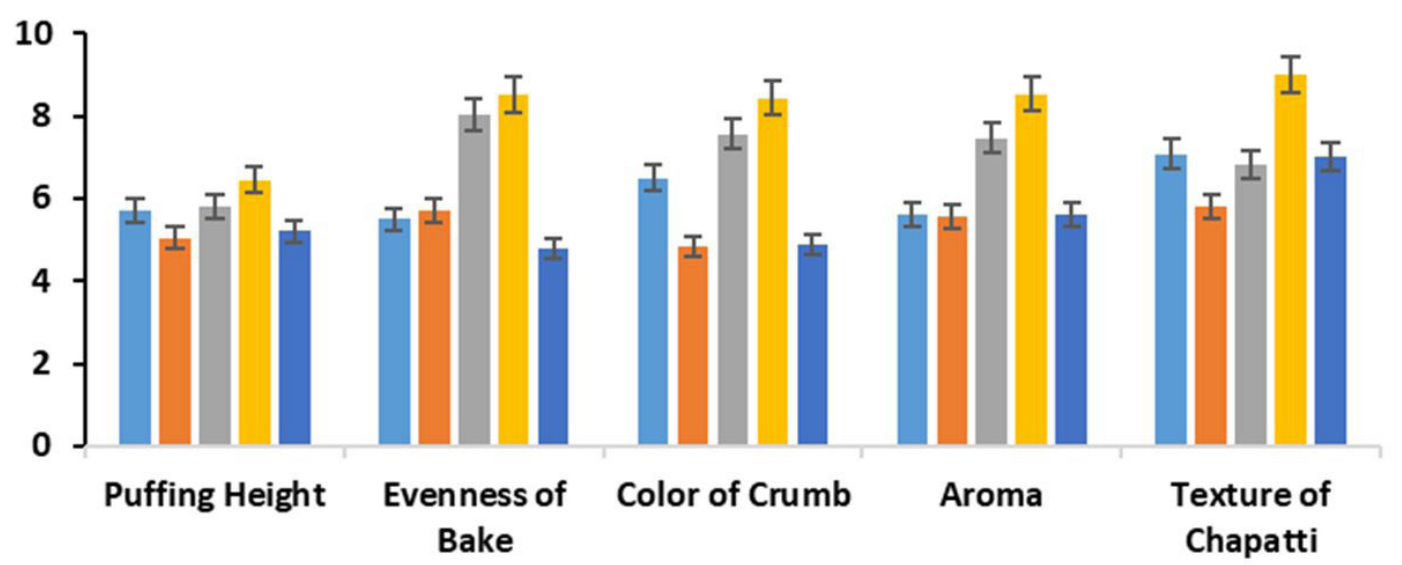

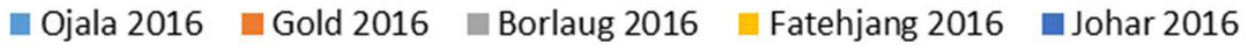

Figure 5. Graphical results shown sensory evaluation of different wheat varieties.

softness. As evident from the above statements and comparative overview, the chapattis made from wheat cultivars Gold 2016 and Fatehjang 2016 showed increased tendency of likeness by the sensory panel in terms of sensory attributes.

\section{Conclusion}

Wheat is widely consumed all over the world including Pakistan where chapatti made from wheat flour is the traditional staple food consumed by majority of people in Pakistan. The aim of this study was to evaluate the physical, chemical, rheological and sensory properties of assess the effects of recently introduced five cultivars of wheat (Ojala 2016, Borlaug 2016, Johar 2016, Gold 2016 and Fatehjang 2016) in Pakistan and their chappati-making properties. This study has clearly indicated that physicochemical, rheological and sensory properties of different recently introduced wheat cultivars showed significant $(p<0.05)$ variability. The flours obtained from wheat cultivars Fatehjang 2016, Borlaug 2016 and Gold 2016 demonstrated increasing tendency in protein content and dry and wet gluten. Wet gluten was significantly higher in Fatehjang 2016 (30.08\%) and significantly lower (26.21\%) in wheat variety named Gold 201. Fatehjang 2016 and Borlaug 2016 showed the most appealing physical properties among all cultivars. On the basis of rheological and sensory parameters, Fatehjang 2016 was found to be the most suitable variety for production of chapatti followed by Borlaug 2016. Hence, these findings may provide insight for bakers and millers to select best suited cultivar for product formulation and intended applications.

\section{References}

Abramson, D., Hulasare, R., York, R. K., White, N. D. G., \& Jayas, D. S. (2005). Mycotoxins, ergosterol, and odor volatiles in durum wheat during granary storage at $16 \%$ and $20 \%$ moisture content. Journal of
Stored Products Research, 41(1), 67-76. http://dx.doi.org/10.1016/j. jspr.2003.11.002.

American Association of Cereal Chemists - AACC. (2000). Approved methods of American Association of Cereal Chemists (18th ed.). Minnesota: AACC Press. https://doi.org/10.1016/s0144-8617(01)00358-7.

Amir, R. M., Anjum, F. M., Khan, M. I., Khan, M. R., Pasha, I., \& Nadeem, M. (2013). Application of Fourier transform infrared (FTIR) spectroscopy for the identification of wheat varieties. Journal of Food Science and Technology, 50(5), 1018-1023. http://dx.doi. org/10.1007/s13197-011-0424-y. PMid:24426012.

Asim, S. M., Ahmed, A., Amir, R. M., \& Nadeem, M. (2018). Comprehensive identification and evaluation of selected wheat cultivars for their relationship to pan bread quality. Journal of Food Processing and Preservation, 42(7), e13670. http://dx.doi.org/10.1111/jfpp.13670.

Crist, E., Mora, C., \& Engelman, R. (2017). The interaction of human population, food production, and biodiversity protection. Science, 356(6335), 260-264. http://dx.doi.org/10.1126/science.aal2011. PMid:28428391.

Khan, M., Mahesh, C., Semwal, A. D., \& Sharma, G. (2015). Effect of spinach powder on physico-chemical, rheological, nutritional and sensory characteristics of chapati premixes. Journal of Food Science and Technology, 52(4), 2359-2365. http://dx.doi.org/10.1007/s13197013-1198-1. PMid:25829620.

Kihlberg, I., Johansson, L., Kohler, A., \& Risvik, E. (2004). Sensory qualities of whole wheat pan bread: influence of farming system, milling and baking technique. Journal of Cereal Science, 39(1), 67-84. http://dx.doi.org/10.1016/S0733-5210(03)00067-5.

Kundu, M., Khatkar, B. S., \& Gulia, N. (2017). Assessment of chapatti quality of wheat varieties based on physicochemical, rheological and sensory traits. Food Chemistry, 226, 95-101. http://dx.doi. org/10.1016/j.foodchem.2016.12.046. PMid:28254025.

Li, Y., Wu, Y., Hernandez-Espinosa, N., \& Peña, R. J. (2013). The influence of drought and heat stress on the expression of end-use quality parameters of common wheat. Journal of Cereal Science, 57(1), 73-78. http://dx.doi.org/10.1016/j.jcs.2012.09.014.

Maity, A., Vijay, D., Mukherjee, A., \& Lamichaney, A. (2016) Potential impacts of climate change on quality seed production: 
a perspective of hill agriculture. In J. K. Bisht, V. S. Meena, P. K. Mishra \& A. Pattanayak (Eds.), Conservation agriculture (Chap. 5, pp. 459-485). Singapore: Springer. http://dx.doi.org/10.1007/978981-10-2558-7_18

Mueen-ud-Din, G., Salim-ur-Rehman, F. M. A., Nawaz, H., \& Murtaza, M. A. (2010). Effect of wheat flour extraction rates on flour composition, farinographic characteristics and sensory perception of sourdough naans. International Journal of Biological, Biomolecular, Agricultural. Food and Biotechnological Engineering, 4(8), 668-674.

Mutwali, N. I. A. K. (2011). Quality of wheat cultivars grown in different locations of Sudan for bread making (Ph.D. dissertation). University of Khartoum, Khartoum, Sudan.

Mutwali, N. I., Mustafa, A. I., Gorafi, Y. S., \& Mohamed Ahmed, I. A. (2016). Effect of environment and genotypes on the physicochemical quality of the grains of newly developed wheat inbred lines. Food Science \& Nutrition, 4(4), 508-520. http://dx.doi.org/10.1002/ fsn3.313. PMid:27386101.

Ribotta, P. D., León, A. E., \& Añón, M. C. (2001). Effect of freezing and frozen storage of doughs on bread quality. Journal of Agricultural and Food Chemistry, 49(2), 913-918. http://dx.doi.org/10.1021/ jf000905w. PMid:11262049.

Tahseen, O., Abdallah, J., \& Omar, J. A. (2014). In situ degradability of dry matter, crude protein, acid and neutral detergent fiber of olive cake and greenhouse wastes of tomato and cucumber. Revue de Medecine Veterinaire, 165(3), 93-98.

Villanueva, N. D., Petenate, A. J., \& Da Silva, M. A. (2005). Performance of the hybrid hedonic scale as compared to the traditional hedonic, self-adjusting and ranking scales. Food Quality and Preference, 16(8), 691-703. http://dx.doi.org/10.1016/j.foodqual.2005.03.013.

Wani, I. A., Sogi, D. S., Sharma, P., \& Gill, B. S. (2016). Physicochemical and pasting properties of unleavened wheat flat bread (Chapatti) as affected by addition of pulse flour. Cogent Food \& Agriculture, 2(1), 1124486. http://dx.doi.org/10.1080/23311932.2015.1124486.

Zabed, H., Boyce, A. N., Sahu, J. N., \& Faruq, G. (2017). Evaluation of the quality of dried distiller's grains with solubles for normal and high sugary corn genotypes during dry-grind ethanol production. Journal of Cleaner Production, 142, 4282-4293. http://dx.doi.org/10.1016/j. jclepro.2016.11.180. 